\title{
Linkage between ABO Blood Type and Occupation: Evidence from Japanese Politicians and Athletes
}

\author{
Masayuki Kanazawa $^{1}$ \\ ${ }^{1}$ Human Sciences ABO Center, Tokyo, Japan \\ Correspondence: Masayuki Kanazawa, Human Sciences ABO Center, Tokyo, Japan.
}

Received: July 5, 2021

Accepted: August 9, 2021

Available online: August 17, 2021

doi:10.11114/ijsss.v9i5.5282

URL: https://doi.org/10.11114/ijsss.v9i5.5282

\begin{abstract}
In Asian countries, e.g., Japan, South Korea, China and Taiwan, many studies on the relationship between ABO blood type and personality have been conducted. Recently, it has been estimated that more than half of Japanese, Korean and Taiwanese people feel that this relationship is legitimate. Therefore, when data from these countries are used in personality tests, it is theoretically difficult to eliminate the effects of the "contamination of knowledge," even if differences are found. To avoid this issue, this study examined the linkage between ABO blood type and occupations in Japan. The results showed that personality traits corresponding to blood type appeared in the data of each of the three groups of politicians and athletes, and all differences were statistically significant. We observed a clear and significant relationship between blood type and personality. Additionally, it is also necessary to consider the influence of social background.
\end{abstract}

Keywords: ABO blood type, personality, occupation, politician, athlete

\section{Introduction}

\subsection{Background}

Currently, the effect of genetic factors on personality is estimated to be approximately 50\% (Ando et al., 2004; Gerra et al., 2000; Keller et al., 2005). The ABO blood type, discovered by Landsteiner in 1901, is a genetically determined and easily measured biological marker. Hence, much research has been conducted not only on health risks, but also on its impact on personality. In Japan, South Korea, and Taiwan, roughly half of the populations feel the relationship between blood type and personality is legitimate (Cho et al., 2005; Kamise \& Matsui, 1994; Sato \& Watanabe, 1992; Wu, et al., 2005; Yamaoka, 2009).

Presently, more than half of the Japanese population believes in the relationship between blood type and personality. For example, in an online questionnaire conducted in 2015 by Fuji Television Networks, one of the major television networks in Japan, 68.7\% of the 201,119 respondents believed in the relationship (Fuji Television Networks, 2015). Prior surveys have returned similar results. In a 1986 survey conducted by NHK, the Japanese public broadcaster, 75\% of the 1,102 respondents believed in the relationship (NHK Broadcasting Culture Research Institute, 1986).

\subsection{Blood Type Personality Theory}

The relationship between blood type and personality is studied at an international scale, and the first academic examination using statistics as a base was conducted in 1927, by Furukawa, a Japanese educational psychologist (Furukawa, 1927 \& 1930; Nawata, 2014; Rogers \& Glendon, 2003; Sato \& Watanabe, 1992; Wang, 2014; Wu et al., 2005). However, the paradigm that most influences present-day research is from a Japanese book (Nomi, 1971) published in 1971 by Nomi, an independent Japanese researcher (Nawata, 2014; Rogers \& Glendon, 2003; Sato \& Watanabe, 1992 Wang, 2014).

Nomi's research (Table 1) further developed Furukawa's theory. He adopted the multiple method approach, which consisted of questionnaires on the traits of people's behavior and mindset, surveys of blood type distribution for various occupations and groups, and observations and statistical analyses of human behavior. The sample sizes of these studies were claimed to be tens of thousands in total. He also suggested an association with disease and physical constitution (Nomi, 1978). 
Table 1. Blood Type, Personality, and Occupations with High Distribution Rates

\begin{tabular}{|c|c|c|}
\hline Blood Type & Personality & High Distribution Rate \\
\hline A & $\begin{array}{l}\text { Have a sense of duty for "someone." Suppress emotions and } \\
\text { desires. Compassionate. Value perceptions of others. Observe } \\
\text { rules, customs, and order; avoid extremes. On the other hand, a } \\
\text { bit conventional. Very consistent. More stubborn and } \\
\text { short-tempered than other groups. }\end{array}$ & $\begin{array}{l}\text { Education minister } \\
\text { High-ranking sumo } \\
\text { wrestler }\end{array}$ \\
\hline $\mathrm{B}$ & $\begin{array}{l}\text { Self-paced. Reluctant to be argued with or restrained. } \\
\text { Cognitively flexible, highly innovative and accepting of new } \\
\text { people. Least influenced by their surroundings, unconcerned; } \\
\text { most careless. In general, not particular about things. }\end{array}$ & Baseball hitter \\
\hline $\mathrm{O}$ & $\begin{array}{l}\text { Strong desire to live, full of vitality. Strongly goal oriented. } \\
\text { Naked openness with and parental love for best friends and } \\
\text { family. On the other hand, very wary of outsiders and the } \\
\text { unknown. }\end{array}$ & $\begin{array}{l}\text { Prime minister } \\
\text { Foreign minister } \\
\text { Baseball hitter }\end{array}$ \\
\hline $\mathrm{AB}$ & $\begin{array}{l}\text { Rational, businesslike. Have both a calm, cool, stable side and } \\
\text { an easily disturbed side with sentimental fragility. Very friendly } \\
\text { and tidy; treat with kindness when asked; smiling. Somewhat } \\
\text { aloof. }\end{array}$ & $\begin{array}{l}\text { Foreign minister } \\
\text { Education minister }\end{array}$ \\
\hline
\end{tabular}

Source: Nomi (1978)

\subsection{Results of Academic Studies}

Although there are many academic studies using multiple-item personality tests, the inconsistency among results (Alsadi, 2020; Cattell et al., 1964; Cho et al., 2005; Cramer \& Imaike, 2002; Flegr et al., 2013; Furukawa, 1927 \& 1930; Gupta, 1990; Jogawar, 1983; Kim et al., 2007; Lester \& Gatto, 1987; Mao et al., 1991; Nawata, 2014; Rogers \& Glendon, 2003; Sharifi et al., 2015; Sato \& Watanabe, 1992; Shimizu \& Ishikawa, 2011; Wu et al., 2005) has led to the endless academic controversy about whether or not the relationship is scientifically confirmed. Many studies examined the association between blood type and personality using the "Big Five" personality test (Costa \& McCrae, 1992; Goldberg, 1990 \& 1992), which has been used extensively in contemporary psychology (Appendix); none of these results have been verified as consistent (Alsadi, 2020; Cho et al., 2005; Cramer \& Imaike, 2002; Flegr et al., 2013; Rogers \& Glendon, 2003; Sharifi et al., 2015; Shimizu \& Ishikawa, 2011; Wu et al. 2005).

On the contrary, several studies have reported differences, mainly in Japan, South Korea, China, and Taiwan. One of the reasons for this is that is that previous studies used multi-item scales such as the Big Five test, whereas these studies usually used a single-item scales based on Mr. Nomi's blood type personality theory (Table 1). Archetypical sample sizes of these were 6,660 (Yamaoka, 2009), 11,766 (Matsui, 1991), 32,347 (Sakamoto \& Yamazaki, 2004; Yamazaki \& Sakamoto, 1991 - these two used the same sample) and over 200,000 (Muto et al., 2012; our estimation; the exact number was not specified in this report, although it was alluded that the size was much larger than the preceding ones). Nevertheless, no consistent statistical difference in respondents without knowledge of the blood type personality theory have been confirmed to date. The current scientific consensus is that the differences that have been found are self-fulfilling phenomena induced by the "contamination by knowledge" (Cramer \& Imaike, 2002; Eysenck \& Nias, 1982; Kim et al., 2007; Matsui, 1991; Ryu \& Sohn, 2007; Sakamoto \& Yamazaki, 2004; Sato \& Watanabe, 1992; Yamaoka, 2009; Yamazaki \& Sakamoto, 1991).

Several studies have also examined medical factors, such as the linkage of the disequilibrium between the DBH and ABO genes, to determine whether physical constitution affects personality (Hobgood, 2011 \& 2021). In 2015, a genotype of blood type and the TCI personality test (Appendix) were determined to be related, as predicted by blood type personality theory (Tsuchimine et al., 2015). It is understood that personality involves complex interactions of genetic factors such as gender and age, and such interactions between these factors are typically non-linear (Kawamoto et al., 2012; Lehmann et al., 2013; Soto et al., 2011).

Since 2020, several studies have stated that statistical relationships have been observed using artificial intelligence (AI) (Akbur et al., 2020; Kanazawa, 2021). Current AI technology often uses a technique called machine learning (LeCun et al., 2015). The technology is based on a neural network that consists of perceptrons, which simulate the mechanisms of human neurons in a multilayered network. This makes it feasible to learn various characteristics contained in the data with dramatically high accuracy, in comparison with the conventional techniques, especially when handling non-linear data. 


\subsection{Blood Type and Occupations}

Eysenck and Nias (1982), personality psychologists, suggest that to avoid "contamination by knowledge" such as astrology, researchers should focus on the occupations people choose rather than on subjective self-assessment. They cited several examples in their book. However, the results in their case were generally negative.

Following their suggestions, several academic studies have examined the relationship between blood type and occupation; significant differences were reported, especially among politicians and athletes. For example, Ohmura, Ukitani and Fujita (2013), a group of Japanese psychologists, said "many Japanese prime ministers were type O (statistically significant at $p$ < 0.05)." Nomi (1978) previously explained that type O was the most "political" of the four types, and athletes tend to be type $\mathrm{O}$ in general. A 2017 Italian study said that type O individuals were good athletes, particularly in long-distance running (Lippi et al., 2017). A 2009 Serbian study observed that the frequency of the blood type $O$ was higher in elite water polo players than other blood types (Cvjeticanin \& Marinkovic, 2009). The result of another 2018 Serbian study on soccer players similarly supported the existence of a relationship between blood type and athletic ability (Ichikawa \& Slobodan, 2018).

\section{Methods}

As previously mentioned, in Japan, more than half of the population is interested in blood type personality theory. For this reason, the blood types of politicians and athletes are introduced in many biographies (e.g., Kokusei Joho Center, 2021), and in some cases they are published on official websites. Rosters are listed in the Supplementary File.

We set the alpha level to 0.05 . A $\chi 2$-test was used to analyze blood type distributions. According to the Japan Red Cross Blood Center, the average distributions of Japanese blood types were $\mathrm{A}=0.391, \mathrm{~B}=0.215, \mathrm{O}=0.299, \mathrm{AB}=0.100$ (Okubo, 1997).

\section{Results}

\subsection{Analysis 1: Blood Type and Japanese Politicians}

As shown in Table 2, type $\mathrm{O}$ was the most common blood type among Japanese prime ministers and foreign ministers at $p$ $=0.026$ and $p=0.010$ respectively, while type A was the most common type among education ministers at $p=0.016$. These results were in agreement with Nomi's study (Table 1).

Table 2. Blood Type Distributions of Japanese Politicians after WWII (as of May, 2021)

\begin{tabular}{|c|c|c|c|c|c|c|c|}
\hline \multirow{2}{*}{ Politicians } & \multicolumn{5}{|c|}{ Numbers of Ministers } & \multirow{2}{*}{$\chi^{2}$} & \multirow{2}{*}{$p$} \\
\hline & $\mathbf{A}$ & B & $\mathbf{O}$ & $\mathbf{A B}$ & N/A & & \\
\hline Prime Minister & $\begin{array}{c}0.294 \\
(10)\end{array}$ & $\begin{array}{c}0.118 \\
(4)\end{array}$ & $\begin{array}{c}0.529 \\
(18)\end{array}$ & $\begin{array}{c}0.059 \\
(2)\end{array}$ & $\begin{array}{c}- \\
(0)\end{array}$ & 9.300 & 0.026 \\
\hline Foreign Minister & $\begin{array}{c}0.324 \\
(12)\end{array}$ & $\begin{array}{c}0.054 \\
(2)\end{array}$ & $\begin{array}{c}0.405 \\
(15)\end{array}$ & $\begin{array}{c}0.216 \\
(8)\end{array}$ & $\begin{array}{c}- \\
(4)\end{array}$ & 11.438 & 0.010 \\
\hline Education Minister & $\begin{array}{c}0.365 \\
(19)\end{array}$ & $\begin{array}{c}0.192 \\
(10)\end{array}$ & $\begin{array}{c}0.212 \\
(11)\end{array}$ & $\begin{array}{c}0.231 \\
(12)\end{array}$ & $\begin{array}{c}- \\
(22)\end{array}$ & 8.574 & 0.016 \\
\hline Average in Japan & 0.391 & 0.215 & 0.299 & 0.100 & - & - & - \\
\hline
\end{tabular}

Note. The numbers of people in each subcategory are in parentheses. Most common blood type for each occupation is highlighted in bold; $p<0.05$ are also highlighted in bold.

\subsection{Analysis 2: Blood Type and Japanese Athletes}

As shown in Table 3, type $\mathrm{O}$ was the most common type for Japanese baseball hitters at $p=0.040$ for the top 20 home run hitters in Nippon Professional Baseball (NPB) history. This result was consistent with Nomi's study (Table 1). Also, O was the most common type for Japanese soccer players, at $p=0.064$ for the top 20 goal-scorers in J League history, and at $p=0.002$ for the members of Japan's FIFA World Cup teams (1998-2018). The former was statistically significant at $p=$ 0.008 when calculated using the binomial distribution, since no one in the group had type B. 
Table 3. Blood Type Distributions of Japanese Athletes (2020)

\begin{tabular}{|c|c|c|c|c|c|c|c|}
\hline \multirow{2}{*}{ Athletes } & \multicolumn{5}{|c|}{ Number of Athletes } & \multirow{2}{*}{$\chi^{2}$} & \multirow{2}{*}{$p$} \\
\hline & $\mathbf{A}$ & B & $\mathbf{O}$ & $\mathbf{A B}$ & N/A & & \\
\hline Baseball (NPB) & $\begin{array}{c}0.158 \\
(3)\end{array}$ & $\begin{array}{c}0.211 \\
(4)\end{array}$ & $\begin{array}{c}0.579 \\
(11)\end{array}$ & $\begin{array}{c}0.053 \\
(1)\end{array}$ & $\begin{array}{l}- \\
\text { (1) }\end{array}$ & 8.316 & 0.040 \\
\hline Soccer (J League) & $\begin{array}{c}0.381 \\
(8)\end{array}$ & $\begin{array}{c}0.000 \\
(0)\end{array}$ & $\begin{array}{c}0.476 \\
(10)\end{array}$ & $\begin{array}{c}0.143 \\
(3)\end{array}$ & $\begin{array}{l}- \\
(0)\end{array}$ & 7.277 & 0.064 \\
\hline Soccer (World Cup) & $\begin{array}{c}0.293 \\
(39)\end{array}$ & $\begin{array}{c}0.150 \\
(20)\end{array}$ & $\begin{array}{c}0.406 \\
(54)\end{array}$ & $\begin{array}{c}0.150 \\
(20)\end{array}$ & $\begin{array}{c}- \\
(0)\end{array}$ & 14.886 & 0.002 \\
\hline Average in Japan & 0.391 & 0.215 & 0.299 & 0.100 & - & - & - \\
\hline
\end{tabular}

Note. The numbers of people in each subcategory are in parentheses. Most common blood type for each occupation is highlighted in bold; $p<0.05$ are also highlighted in bold.

\section{Discussions}

The physiological function of $\mathrm{ABO}$ blood type remains a mystery. However, it is now clear that having one specific blood type may play an important role in health (Ewald \& Sumner, 2016). For example, several studies found that individuals with type A were more susceptible to COVID-19, whereas individuals with type O were less susceptible (Barnkob et al., 2020; Hoiland et al., 2020; Severe Covid-19 GWAS Group, 2020).

Nomi stated that type $\mathrm{O}$ was the most "political" of the four types, and that $\mathrm{O}$ would be most common for prime ministers and defense ministers due to their interest in power. On the contrary, type A, with its strong sense of ethics and order, would be more prevalent among education ministers (Table 1).

Nomi (1978) also stated that athletes tend to be type $\mathrm{O}$ in general. An Italian study said that type $\mathrm{O}$ individuals are good athletes, particularly in long-distance running (Lippi et al., 2017). In Japan, type O persons tend to be the best hitters in professional baseball. Moreover, of the 10 Japanese table tennis players in the top five of the June 2021 world rankings for men and women, seven were type $\mathrm{O}$ (Supplementary File). The blood type personality theory also explains that type B individuals "look for a life with much freedom." Consistent with this theory, athletes in team sports such as soccer had fewer type B athletes than baseball hitters (Table 3) or table tennis players who play individually. In Japanese women's synchronized (artistic) swimming, of the 20 swimmers whose blood types were known, only two were type B; this is only half of what would be expected given the frequency of type B among the general population of Japan, although it should also be pointed out that there were a quite number of swimmers whose blood types were unknown (Supplementary File). Thus, in politicians and athletes, there appear to be distinct, statistically significant differences predicted by blood type. These can be recognized as evidence that blood type is related to health, sports, and personality.

\section{Conclusions}

The results showed that personality traits corresponding to blood type appeared in the data of each of the three groups of politicians and athletes, and all differences were statistically significant. We observed a clear and significant relationship between blood type and personality.

Our findings provide a hypothetical but new framework of how genes affect human personality. On the other hand, the subjects in this study were limited to Japanese populations. Further research with a larger, more global dataset is needed to address the true implications of blood type and personality.

\section{Acknowledgements}

The author sincerely appreciates the support of Chieko Ichikawa, President of the Human Sciences ABO Center, and the suggestions of Professor Qinglai Meng of Oregon State University. The author is also grateful to Fred Wong, co-founder of AI Hong Kong Limited, for his help in further understanding AI.

\section{References}

Akbar, A. T., Husaini, R., Akbar, B. M., \& Saifullah, S. (2020). A proposed method for handling an imbalance data in classification of blood type based on Myers-Briggs type indicator. Jurnal Teknologi dan Sistem Komputer, 8(4), 276-283. https://doi.org/10.14710/jtsiskom.2020.13625

Alsadi, R. (2020). Personality Traits and Their Relationship with Blood Groups among of Palestinian University Students, International Journal of Psychology and Behavioral Sciences, 10(2), 34-42. 
http://article.sapub.org/10.5923.j.ijpbs.20201002.02.html

Ando, J., Suzuki, A., Yamagata, S., Kijima, N., Maekawa, H., Ono, Y., \& Jang, K. L. (2004). Genetic and environmental structure of Cloninger's temperament and character dimensions. Journal of Personality Disorders, 18(4), 379-93 https://doi.org/10.1521/pedi.18.4.379.40345

Barnkob, M, B. Pottegård, A. Støvring, H. Haunstrup, T, M. Homburg, K. Larsen, R. Hansen, M, B. \& Titlestad, K. (2020). Reduced prevalence of SARS-CoV-2 infection in ABO blood group O. Blood Advances. 2020 Oct 27; 4(20), 4990-4993. https://doi.org/ 10.1182/bloodadvances.2020002657

Cattell, R. B., Boutourline, H. Y., \& Hundleby, J. D. (1964). Blood groups and personality traits. American Journal of Human Genetics, 16, 397-402.

Cho, S. H., Suh, E. K. M., \& Ro, Y. J. (2005). Beliefs about Blood Types and Traits and their Reflections in Self-reported Personality. Korean Journal of Social and Personality Psychology, 19(4), 33-47.

Cloninger, C. R. (1987). A systematic method for clinical description and classification of personality variants. Archives Of General Psychiatry, 44, 573-588. https://doi.org/10.1001/ archpsyc.1987.01800180093014

Costa, P. T., Jr., \& McCrae, R. R. (1992). The NEO-P-I-R professional manual: Revised NEO Personality Inventory. (NEO-P-I-R) and NEO Five-Factor Inventory (Neo-FFI). Odessa, Fla: Psychological Assessment Resources.

Cramer, K. M., \& Imaike, E. (2002). Personality, blood type, and the five-factor model. Personality and Individual Differences, 32, 621-626. https://doi.org/10.1016/S0191-8869(01)00064-2

Cvjeticanin S., \& Marinkovic, D. (2009). Morphogenetic variability during selection of elite water polo players. Journal Of Sports Sciences, 27(9), 941-7. https://doi.org/10.1080/02640410902960494

Ewald, D. R., \& Sumner, S. C. (2016). Blood type biochemistry and human disease. Wiley Interdisciplinary Reviews: Systems Biology and Medicine, 8(6), 517-535. https://doi.org/ 10.1002/wsbm.1355

Eysenck, H. J., \& Nias, D. K. B., (1982). Astrology: Science or Superstition?. London: Curtis Brown Temple Smith.

Flegr, J., Preiss, M., \& Klose, J. (2013). Toxoplasmosis-associated difference in intelligence and personality in men depends on their Rhesus blood group but not ABO blood group. PLoS One, 8, e61272. https://doi.org/10.1371/journal.pone.0061272

Fuji Television Networks. (2015). Nippon no Daimondai. (November 8, 2015). Fuji Television Networks (Tokyo, Japan).

Furukawa, T. (1927). A study of temperament by means of human blood groups. Japanese Journal of Psychology, 2(4), 612-634. https://doi.org/10.4992/jjpsy.2.612

Furukawa, T. (1930). A study of temperament and blood groups. Journal of Social Psychology. 1, $494-509$. https://doi.org/ 10.1080/00224545.1930.9714153

Gerra, G., Zaimovic, A., Timpano, M., Zambelli, U., Delsignore, R., \& Brambilla, F. (2000). Neuroendocrine correlates of temperamental traits in humans. Psychoneuroendocrinology, 25, 479-964. https://doi.org/10.1016/s0306-4530(00)00004-4

Goldberg, L. R. (1990). An alternative "description of personality": the big-five factor structure. Journal of Personality and Social Psychology, 59(6), 1216-29. https://doi.org/10.1037/0022-3514.59.6.1216

Goldberg, L. R. (1992). The development of markers for the big-five factor structure. Psychological Assessment, 4, 26-42. https://doi.org/ 10.1037/1040-3590.4.1.26

Gupta, S. (1990). Blood groups and personality characteristics. Personality and Individual Differences, 3, $317-318$. https://doi.org/10.1016/0191-8869(90)90246-N

Hobgood, D. K. (2011). Personality traits of aggression-submissiveness and perfectionism associate with ABO blood groups through catecholamine activities. Medical Hypotheses, 77, 294-300. https://doi.org/10.1016/j.mehy.2011.04.039

Hobgood, D. K. (2021). ABO B gene is associated with introversion personality tendencies through linkage with dopamine beta hydroxylase gene. Medical Hypotheses, 148, 110513. https://doi.org/ 10.1016/j.mehy.2021.110513

Hoiland, R, L. Fergusson, N, A. Mitra, A, R. Griesdale, D, E. G. Devine, Dana, V. Stukas, S. Cooper, J. et al. The association of $\mathrm{ABO}$ blood group with indices of disease severity and multiorgan dysfunction in COVID-19. Blood Advances, 2020 Oct 27;4(20), 4981-4989. https://doi.org/ 10.1182/bloodadvances.2020002623

Ichikawa, C., \& Slobodan, P. (2018). ABO system of blood types and positions in soccer team. Belgrade: New Look 
Entertainment.

Jogawar, V. V. (1983). Personality correlates of human blood groups. Personality and Individual Differences, 4, $215-216$. https://doi.org/10.1016/0191-8869(83)90026-0

Kamise, Y., \& Matsui, Y. (1994). Functions and structure of blood-group stereotype. Bulletin of University of the Sacred Heart, 82, 90-111.

Kanazawa, M. (2021). A pilot study using AI for psychology: ABO blood type and personality traits, American Journal of Intelligent Systems, 11(1), 1-7. Retrieved from http://article.sapub.org/10.5923.j.ajis. 20211101.01.html

Kawamoto, T., Oshio, A., Abe, S., Tsubota, Y., Hirashima, T., Ito, H., \& Tani, I. (2015). Age and gender differences of Big Five personality traits in a cross-sectional Japanese sample. Japanese Journal of Developmental Psychology, 26(2), 107-122. https://doi.org/ 10.11201/jjdp.26.107

Keller, M. C., Coventry, W. L., Heath, A. C., \& Martin, N. G. (2005). Widespread evidence for non-additive genetic variation in Cloninger's and Eysenck's personality dimensions using a twin plus sibling design, Behavior Genetics, 35, 707-21. https://doi.org/10.1007/s10519-005-6041-7

Kijima, N., Saito, R., Takeuchi, M., Yoshino I., Ono, Y., Kato, M., \& Kitamura, T. (1996). Cloninger's seven-factor model of temperament and character and Japanese version of Temperament and Character Inventory (TCI). Kikan Seishinka Shindangaku, 7, 379-399.

Kim, B. M., Lee, D. M., Lee, S. H., \& Gim, W. S. (2007). Blood-type distribution. Physica A: Statistical Mechanics and its Applications, 373, 533-540. https://doi.org/10.1016/j.physa. 2006.05.027

Kokusei Joho Center. (2021). Kokkai Yoran. Tokyo: Kokusei Joho Center.

Kunisato, Y., Yamaguchi, A., \& Suzuki, S. (2008). Cloninger's Temperament and character model and the Big Five. Japanese Journal of Personality, 16(8), 323-324. https://doi.org/10.2132/ personality.16.324

LeCun, Y., Bengio, \& Y., Hinton, G. (2015). Deep learning. Nature, 521(7553), $436-44$. https://doi.org/10.1038/nature14539

Lehmann, R., Denissen, J. J., Allemand, M., \& Penke, L. (2013). Age and gender differences in motivational manifestations of the Big Five from age 16 to 60. Developmental Psychology, 49(2), 365-83. https://doi.org/10.1037/a0028277

Lester, D., \& Gatto, J. (1987). Personality and blood group. Personality and Individual Differences, 8, 267. https://doi.org/10.1016/0191-8869(87)90184-X

Lippi, G., Gandini, G., Salvagno, G. L., Skafidas, S., Festa, L., Danese, E., \& Schena, F. (2017). Influence of ABO blood group on sports performance. Annals of Translational Medicine, 5(12), 255. https://doi.org/10.21037/atm.2017.04.33

Mao, X., Xu, M., Mu, S., Ma, Y., \& He, M. (1991). Study on relationship between human ABO blood A group and type A behavior pattern. Hua Xi Yi Ke Da Хие Хие Bao, 22(1), 93-96.

Matsui, Y. (1991). A statistical analysis of personality difference by blood type. Bulletin of Tokyo Metropolitan Tachikawa Junior College, 24, 51-54.

Muto, C., Nagashima, M., Harada, J., Abe S., Furuya Y., Kamizon K., \& Konishi Y. (2012). A demonstrative and critical study on pseudo-science for scientific literacy construction at teacher education course. Grants-in-Aid for Scientific Research FY2011 Final Research Report (Japan). Retrieved from https://kaken.nii.ac.jp/en/grant/KAKENHI-PROJECT-22650191/

Nawata, K. (2014). No relationship between blood type and personality: Evidence from large-scale surveys in Japan and the US. Japanese Journal of Psychology, 85(2), 148-156. https://doi.org/ 10.4992/jjpsy.85.13016

NHK Broadcasting Culture Research Institute. (1986). A survey on "scientific technology and life". Tokyo: NHK Service Center (NHK Broadcasting Culture Research Institute, 1986).

Nomi, M. (1971). Understanding compatibility through blood type. Tokyo: Seishun Publishing.

Nomi, M. (1978). New blood type humanics. Tokyo: Sankei Publishing.

Ohmura, M., Ukitani S., \& Fujita S. (2013). Is "blood type personality" reliable? (Report No. 30) I: Is blood type characteristic found among the members of the House of Representatives?. Proceedings of Japan Association of Applied Psychology, 80, 60-61.

Okubo, Y. (1997). Pretransfusion testing with special reference to blood groups in Japanese (2nd ed.) (p. 4). Tokyo: 
Ishiyaku Publishers.

Rogers, M., \& Glendon, A. I. (2003). Blood type and personality. Personality and Individual Differences, 34, $1099-1112$. https://doi.org/10.1016/S0191-8869(02)00101-0

Ryu, S. I., \& Sohn, Y. W. (2007). A review of sociocultural, behavioral, biochemical analyzes on ABO blood-groups typology. Korean Journal of Social and Personality Psychology, 21(3), 27-55. https://doi.org/10.21193/kjspp.2007.21.3.003

Sakamoto, A., \& Yamazaki, K. (2004). Blood-typical personality stereotypes and self-fulfilling prophecy: A natural experiment with time-series data of 1978-1988. Progress in Asian Social Psychology, 4, 239-262. Seoul: Kyoyook-KwahakSa.

Sato, T., \& Watanabe, Y. (1992). Psychological studies on blood-typing in Japan. Japanese Psychological Review, 35, 234-268. https://doi.org/10.24602/sjpr.35.2_234

Severe Covid-19 GWAS Group. (2020). Genomewide Association Study of Severe Covid-19 with Respiratory Failure. New England Journal of Medicine, 2020 Oct 15; 383(16), 1522-1534. https://doi.org/ 10.1056/NEJMoa2020283

Sharifi, M., Ahmadian, \& H., Jalali, A. (2015). The relationship between the big five personality factors with blood types in Iranian university students. Journal of Chemical and Pharmaceutical Research, 7(5), 233-240.

Shiinonaka, Y., Nakazato, K., Gondo, Y., \& Takayama, M. (1998). Construction and factorial validity of the Japanese NEO-PI-R. Japanese Journal of Personality, 6(2), 138-147. https://doi.org/10.2132/ jjpjspp.6.2_138

Shimizu, T., \& Ishikawa, M. (2011). Relationships between ABO blood types and personality: Measurement by the Five Factor Model. Kozokoseishugi-kenkyu, 5, 78-91.

Soto, C. J., John, O., P., Gosling, S, J., \& Potter, J. (2011). Age differences in personality traits from 10 to 65: Big Five domains and facets in a large cross-sectional sample. Journal of Personality and Social Psychology, 100(2), 330-48. https://doi.org/10.1037/a0021717

Tsuchimine, S., Saruwatari, J., Kaneda, A., \& Yasui-Furukori, N. (2015). ABO blood type and personality traits in healthy Japanese subjects. PLoS One, 10(5), e0126983. https://doi.org/ 10.1371/ journal.pone.0126983

Wada, S. (1996). Construction of the Big Five Scales of personality trait terms and concurrent validity with NPI, Japanese Journal of Psychology, 67(1), 61-67. https://doi.org/10.4992/jjpsy.67.61

Wang, J. Q. (2014). Blood type and personality. Beijing: Beijing Institute of Technology Press.

Weisberg, Y. J., Deyoung, C. G., \& Hirsh, J. B. (2011). Gender differences in personality across the ten aspects of the Big Five. Frontiers in Psychology, 2, 178. https://doi.org/10.3389/fpsyg.2011.00178

Wu, K., Lindsted, K. D., \& Lee, J. W. (2005). Blood type and the five factors of personality in Asia. Personality and Individual Differences, 384, 797-808. https://doi.org/10.1016/j.paid.2004.06.004

Yamaoka, S. (2009). Discrimination and delusion of blood type personality divination. 18th Annual Meeting of Japan Society of Personality Psychology, 18, 11. https://doi.org/10.24534/ amjspp.18.0_11

Yamazaki, K., \& Sakamoto, A. (1991). Self-fulfillment phenomenon generated by blood-typical personality stereotypes: time-series analysis of nation-wide survey. 32nd Annual conference of Japanese society of social psychology, 32, 289-292.

\section{Appendix}

\section{Big Five Personality Test}

There are many types of personality tests used in psychology, depending on the purpose. The "Big Five" test is generally used for blood type and personality studies. The Big Five personality test, as the name implies, comprehensively describes personality by five factors called the Big Five (Costa \& McCrae, 1992; Goldberg, 1990 \& 1992). These five factors are usually called Neuroticism, Extraversion, Openness, Agreeableness, and Conscientiousness. The model collects corpora from dictionaries and traditional personality tests, as well as re-analyses of personality scales, and the five factors are extracted through factor analysis. Thus, the Big Five does not assume any background theory. In other words, it can be said that the Big Five model was constructed as the result of an attempt to broadly describe personalities with as few factors as possible, without assuming any background theory. Thus, the Big Five models are characterized by the bottom-up process, and personality is comprehensively captured by five factors. The NEO-PI-R, commonly used as a Big Five personality test, consists of 60 to 240 question items, each of which is rated using a five-point scale (Costa \& McCrae, 1992; Kunisato et al., 2008; Shiinokaka et al., 1998; Wada, 1996). 
As mentioned above, the Big Five is a questionnaire-based personality assessment, which consists of answering a series of questions regarding multiple self-reported personality traits. These traits integrate into five personality factors by statistical processing. In theory, this means that the self-reported trait will either directly or indirectly appear in the result.

\section{TCI Personality Test}

The Tridimensional Character Inventory (TCI), a top-down personality model, is often used to examine genetic dispositions (Cloninger, 1987; Kijima et al., 1996). This personality test built a model for temperament with a physiological basis in the background. The test consists of 240 items using a yes-no scale rating.

Cloninger hypothesized that personality consists of traits that are hereditary and stable throughout life, and traits mature throughout life under the influence of socio-cultural environments. The TCI consists of seven dimensions, including four temperament dimensions (Novelty Seeking, Harm Avoidance, Reward Dependence, and Persistence) and three character dimensions (Self-directedness, Cooperativeness and Self-transcendence). Three of the temperament dimensions have been hypothesized to be associated with monoamine neurotransmitters: Novelty Seeking has been hypothesized to be associated with dopaminergic, Harm Avoidance with serotonergic, and Reward Dependence with noradrenergic.

\section{Copyrights}

Copyright for this article is retained by the author(s), with first publication rights granted to the journal.

This is an open-access article distributed under the terms and conditions of the Creative Commons Attribution license which permits unrestricted use, distribution, and reproduction in any medium, provided the original work is properly cited. 